74 巻 740 号 $(2008-4)$

\title{
フレキシブル・マスターースレーブシステムの運動とカの制御* （物体との接触時における状態推定精度の改善）
}

\author{
星 野洋 平*1, 小林幸 徳*1, 古田雄祐*2 \\ Motion and Force Control of Flexible Master-Slave System \\ (Improvement of State Estimation During Contacting with Objects) \\ Yohei HOSHINO*3, Yukinori KOBAYASHI and Yusuke FURUTA \\ ${ }^{* 3}$ Graduate School of Engineering, Hokkaido University, \\ N13W8, Sapporo-shi, Hokkaido, 060-8628 Japan

\begin{abstract}
We study the motion, vibration and contact force control of the flexible master-slave system (FMSS). In this study, the master arm is a one-link arm that consists of a rigid body and the slave arm is a one-link arm that consists of a flexible link. The bilateral control based on passivity and the optimal control based on the linear quadratic regulator (LQR) are applied to the system. Each of those control methods has some advantages and disadvantages. We employ the state observer to construct those controllers. However, the accuracy of state estimation is deteriorated while the slave-arm contacts with objects. Therefore we improve the accuracy of the state estimation by applying the disturbance-state observer. We indicate the performance of the present method by experimental results.
\end{abstract}

Key Words : Motion Control, Vibration Control, Observer, Flexible Master-Slave System, Force Control

\section{1. 序論}

危険な環境下での作業を遠隔操作により遂行する方 法としてマスターースレーブタイプのマニピュレータ は古くから用いられてきた. マスターースレーブシス テムに関しては様々な研究が行われており, 通信遅れ (1)(2), 安定性についての問題 ${ }^{(3)}$, 人間の制御特性に関 する研究 ${ }^{(4) \sim(6)}$, 各分野への応用 ${ }^{(7) ~(9)}$ などが報告され ている. これらの研究の多くは剛体アームを想定して おり, スレーブアームを柔軟アームとした場合の研究 はあまり報告されていない. しかし, 宇宙用ロボット アームに代表される長大な柔軟スレーブアームの操作 性などの性能向上のためには更なる研究が必要である.

そこで, 本研究では, 1 リンクの剛体アームをマス ターアームとし, 1 リンクの柔軟アームをスレーブアー ムとするフレキシブル・マスターースレーブシステム (FMSS) を対象とし, 柔軟なスレーブアームが物体に 接触する場合を扱う。そして, 受動性に基づく対称型 バイラテラル制御法とともに, 最適 1 型デジタルサー ボ系を適用して, 運動制御と力制御に関する研究を行

\footnotetext{
* 原稿受付 2007 年 7 月 5 日.

*1 正員, 北海道大学大学院工学研究科(乯060-8628 札幌市北 区北 13 西 8).

*2 学生員, 北海道大学大学院工学研究科 [現: 三菱重工(株)].

E-mail : hoshinoy@eng.hokudai.ac.jp
}

う.オブザーバーを用いて状態フィードバックを行う が, 同一次元オブザーバーを用いた場合は物体への接 触中に状態推定精度が低下する. そこで, 本研究では 接触力による外乱を考慮してオブザーバーの設計を行 うことで, 物体への接触を伴う FMSS の状態推定精度 を改善する.

\section{2. モデリング}

マスターアームは図 1 に示す 1 リンクの剛体アーム とする．マスターアームは直交座標系 $\mathrm{O}_{m}-X_{m} Y_{m}$ の 原点 $\mathrm{O}_{m}$ を軸に回転し, $X_{m}$ 軸からの回転角を $\theta_{m}$ とす る. $m_{m}, l_{m}, J_{m}$ はマスターアームのパラメータであ りそれぞれ質量, アームの長さ, 慣性モーメントを表 す.アームの回転軸に取り付けられたアクチュエータ が発生するトルクを $\tau_{m}$ とし, アーム先端において回 転の接線方向に作用する力を $F_{h}$ とすると, 操作者の 操作力によるトルク $\tau_{h}$ は $\tau_{h}=l_{m} F_{h}$ となる. したがっ て, マスターアームの運動方程式は,

$$
J_{m} \ddot{\theta}_{m}=\tau_{h}+\tau_{m}
$$

と表すことができる．また，マスターアーム全体の力 学的エネルギーは

$$
T_{m}=\frac{1}{2} J_{m} \dot{\theta}_{m}^{2}
$$

となる，スレーブアームは図 2 に示す先端に集中質 


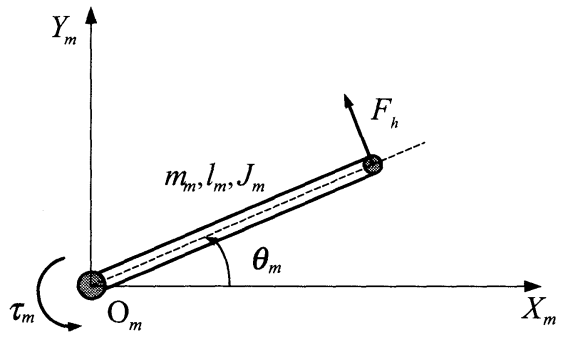

Fig. 1 A model of the master arm

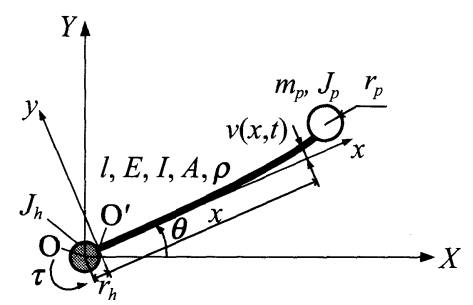

Fig. 2 A model of the slave arm

量を取り付けた 1 リンク柔軟アームとする. 空間に固 定された直交座標系を $O-X Y$ とし，原点 $O$ には半径 $r_{h}$, 慣性モーメント $J_{h}$ のハブが取り付けられ, この 八ブ上の点 $\mathrm{O}^{\prime}$ に長さ $l$, 密度 $\rho$, 縦弾性係数 $E$, 断面 2 次モーメント $I$, 断面積 $A$ の一様な柔軟はりが固定 されている.また, はりの先端には, 半径 $r_{p}$, 質量 $m_{p}$, 慣性モーメント $J_{p}$ の先端質量を有するものとす る. $\mathrm{O}^{\prime}-x y$ は $\mathrm{O}^{\prime}$ を原点とした八ブに固定された座標系 である.八ブの回転角を $\theta, x$ 軸上の位置 $x$ における はりのたわみ変位を $v(x, t)$, ハブに作用するトルクを $\tau$ とする. $\mathrm{O}^{\prime}-x y$ 座標系から O- $X Y$ 座標系への座標変 換行列を $T_{s}$ とすると, 次のような関係が成り立つ.

$\left[\begin{array}{lll}X & Y & 1\end{array}\right]^{T}=\mathbf{T}_{\mathbf{s}}\left[\begin{array}{lll}x & y & 1\end{array}\right]^{T}$

ただし，

$$
\mathbf{T}_{\mathbf{s}}=\left[\begin{array}{ccc}
\cos \theta & -\sin \theta & r_{h} \cos \theta \\
\sin \theta & \cos \theta & r_{h} \sin \theta \\
0 & 0 & 1
\end{array}\right]
$$

である. したがって, 位置 $x$ における柔軟アームの微 小要素の位置ベクトル $\mathbf{p}(x, t)$ は

$$
\mathbf{p}(x, t)=\mathbf{T}_{\mathbf{s}}\left[\begin{array}{lll}
x & v(x, t) & 1
\end{array}\right]^{T}
$$

と表される. また, ペイロードの重心の位置ベクトル $\mathbf{p}_{p}$ は,

$$
\mathbf{p}_{p}(t)=\mathbf{T}_{\mathrm{s}}\left[\left(l+r_{p}\right) v_{e}(t) 1\right]^{T}
$$

となる. ただし, $v_{e}(t)$ はぺイロード重心の $y$ 軸方向の 変位を表しており, 柔軟はりの変形が微小であると仮 定して,

$$
v_{e}(t)=v(l, t)+r_{p} v^{\prime}(l, t)
$$

と近似する. ただし, 次のような演算子

$$
v^{\prime}(x, t)=\frac{\partial v(x, t)}{\partial x}
$$

を新たに定義して用いており, 式 (6) 中の $v^{\prime}(l, t)$ は,

$$
v^{\prime}(l, t)=\left.\frac{\partial v(x, t)}{\partial x}\right|_{x=l}
$$

を表している. 式(4)から式(6) までの関係を用いて, スレーブアーム全体の運動エネルギー $T$ は

$$
T=T_{\text {arm }}+T_{\text {hub }}+T_{\text {payload }}
$$

ただし，

$$
\begin{aligned}
& T_{\text {arm }}=\frac{1}{2} \int_{0}^{l} \rho A \dot{\mathbf{p}}^{T} \dot{\mathbf{p}} d x, \quad T_{h u b}=\frac{1}{2} J_{h} \dot{\theta}^{2}, \\
& T_{\text {payload }}=\frac{1}{2} m_{p} \dot{\mathbf{p}}_{p}^{T} \dot{\mathbf{p}}_{p}+\frac{1}{2} J_{p}\left[\frac{d}{d t}\left(\theta+v^{\prime}(l, t)\right)\right]^{2}
\end{aligned}
$$

であり, ポテンシャルエネルギー $U$ は

$$
U=\frac{1}{2} \int_{0}^{l} E I \nu^{\prime \prime 2}(x, t) d x
$$

となる．また，アクチュエータがトルク $\tau$ を発生する とき, スレーブアームに対する仮想仕事 $\delta W$ は,

$$
\delta W=\tau \delta \theta
$$

となる. 式 (7) から (9) を用いてスレーブアームに対 するラグランジュ関数 $L=T-U$ を求め, ハミルトン の原理を適用すると，ハブに関する運動方程式

$$
\begin{aligned}
& {\left[J_{h}+J_{p}+m_{p} L_{r}^{2}+\int_{0}^{l} \rho A\left(x+r_{h}\right)^{2} d x\right] \ddot{\theta}} \\
& \quad+\int_{0}^{l} \rho A\left(x+r_{h}\right) \ddot{v} d x \\
& \quad+m_{p} L_{r}\left(\ddot{v}(l, t)+r_{p} \ddot{v}^{\prime}(l, t)\right)+J_{p} \ddot{v}^{\prime}(l, t)=\tau
\end{aligned}
$$

柔軟リンクの振動に関する運動方程式

$$
\begin{aligned}
\rho A & {\left[\left(x+r_{h}\right) \ddot{\theta}+\ddot{v}(x, t)\right] } \\
& +E I^{\prime \prime \prime \prime \prime}(x, t)+C E I \dot{v}^{\prime \prime \prime \prime}(x, t)=0
\end{aligned}
$$

ならびに柔軟リンク両端の境界条件式

$$
\begin{aligned}
& v(0, t)=0, \quad v^{\prime}(0, t)=0, \\
& m_{p}\left[L_{r} \ddot{\theta}+\ddot{v}(l, t)+r_{p} \ddot{v}^{\prime}(l, t)\right]=E I v^{\prime \prime \prime}(l, t), \\
& J_{p} \ddot{\theta}+J_{p} \ddot{v}^{\prime}(l, t)+E I v^{\prime \prime}(l, t)+r_{p} E I v^{\prime \prime \prime}(l, t)=0
\end{aligned}
$$

が得られる. ただし, $L_{r}=r_{h}+l+r_{p}$ であり, 式(11) 中のパラメータCはひずみ速度比例型の減衰を考慮し て導入した減衰係数である.

本研究では拘束モード法を用いてたわみ変位をモー ド展開する. 先端質量を有する片持ちはりの第 $i$ 次の 固有振動モードと第 $i$ 次円固有振動数をそれぞれ $\phi_{i}(x)$, $\omega_{i}$ とすると

$$
\phi_{i}{ }^{\prime \prime \prime}(x)-k_{i}^{4} \phi_{i}(x)=0, \quad k_{i}^{4}=\frac{\rho A}{E I} \omega_{i}^{2}
$$

という関係が成り立つ. 対象とする周波数帯域におい て十分な精度を持つ近似系として第 $n$ 次振動モードま 


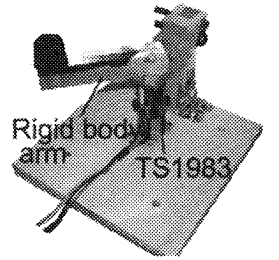

Fig. 3 The master arm

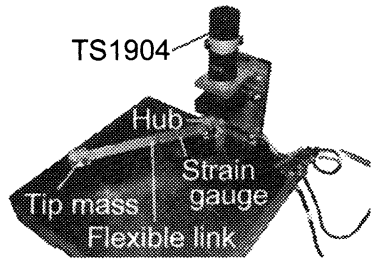

Fig. 4 The slave arm

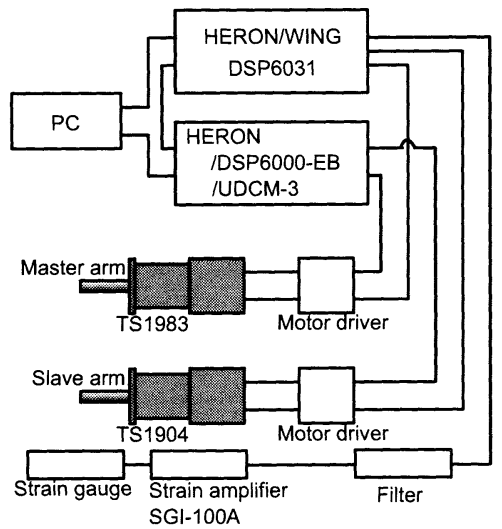

Fig. 5 Experimental setup

でを考慮すると, たわみ変位 $v(x, t)$ は時間関数 $q_{i}(t)$ を 用いて,

$$
v(x, t)=\sum_{i=1}^{n} \phi_{i}(x) q_{i}(t)=\mathbf{W}(x) \mathbf{q}(t)
$$

と展開できる.ただし，

$$
\mathbf{W}(x)=\left[\phi_{1}(x) \cdots \phi_{n}(x)\right], \mathbf{q}(t)=\left[q_{1}(t) \cdots q_{n}(t)\right]^{T}
$$
である. 式(14)を式(10), (11)に代入し振動モードで 直交化すると, 次の有限次元の運動方程式

$$
\mathbf{M} \ddot{\mathbf{z}}+\mathbf{C} \dot{\mathbf{z}}+\mathbf{K z}=\mathbf{D} u
$$

が導かれる.ただし，

$$
\begin{aligned}
& \mathbf{M}=\left[\begin{array}{c|c}
P & \mathbf{Q} \\
\hline \mathbf{Q}^{T} & \mathbf{I}
\end{array}\right], \mathbf{C}=\left[\begin{array}{c|c}
C_{0} & \mathbf{0} \\
\hline \mathbf{0} & \mathbf{R}
\end{array}\right], \mathbf{K}=\left[\begin{array}{l|l}
0 & \mathbf{0} \\
\hline \mathbf{0} & \mathbf{S}
\end{array}\right], \\
& P=J_{h}+J_{p}+\int_{0}^{l} \rho A\left(x+r_{h}\right)^{2} d x+m_{p} L_{r}^{2}, \\
& \mathbf{Q}=\left[Q_{1} \cdots Q_{n}\right], \mathbf{R}=\left[R_{i j}\right], \mathbf{S}=\operatorname{diag}\left[\omega_{1}^{2} \cdots \omega_{n}^{2}\right], \\
& \mathbf{D}=[1 \mid 0 \cdots 0]^{T}, \mathbf{z}=\left[\theta \mid q_{1} \cdots q_{n}\right]^{T}, \quad u=\tau, \\
& Q_{i}=\int_{0}^{l} \rho A\left(x+r_{h}\right) \phi_{i} d x+m_{p} L_{r} \phi_{i}(l) \\
& \quad+\left(m_{p} r_{p} L_{r}+J_{p}\right) \phi_{i}^{\prime}(l) \quad(i=1,2, \cdots, n), \\
& R_{i j}=\int_{0}^{l} C \rho A \omega_{j}^{2} \phi_{i}(x) \phi_{j}(x) d x \quad(i, j=1,2, \cdots, n)
\end{aligned}
$$

である.ここで, ハブの回転に関する減衰を考慮し, 粘性隇衰係数 $C_{0}$ を導入した.これを状態方程式で表 現すれば

$$
\dot{\mathbf{x}}=\mathbf{A} \mathbf{x}+\mathbf{B} u
$$

Table 1 Parameters of the master arm

$$
\begin{array}{ccc}
m_{m} & 1.90 \times 10^{-1} & {[\mathrm{~kg}]} \\
l_{m} & 1.50 \times 10^{-1} & {[\mathrm{~m}]} \\
J_{m} & 1.07 \times 10^{-3} & {\left[\mathrm{~kg} \cdot \mathrm{m}^{2}\right]} \\
\hline
\end{array}
$$

Table 2 Parameters of the slave arm

\begin{tabular}{ccc|ccc}
\hline$\rho$ & $7.70 \times 10^{3}$ & {$\left[\mathrm{~kg} / \mathrm{m}^{3}\right]$} & $l$ & 250 & {$[\mathrm{~mm}]$} \\
$A$ & $1.80 \times 10^{-5}$ & {$\left[\mathrm{~m}^{2}\right]$} & $h$ & 0.6 & {$[\mathrm{~mm}]$} \\
$E$ & 200 & {$[\mathrm{GPa}]$} & $l_{s t}$ & 50 & {$[\mathrm{~mm}]$} \\
$I$ & $5.40 \times 10^{-13}$ & {$\left[\mathrm{~m}^{4}\right]$} & $r_{h}$ & 42 & {$[\mathrm{~mm}]$} \\
$J_{h}$ & $7.29 \times 10^{-5}$ & {$\left[\mathrm{~kg} \cdot \mathrm{m}^{2}\right]$} & $r_{p}$ & 20 & {$[\mathrm{~mm}]$} \\
$J_{p}$ & $1.44 \times 10^{-5}$ & {$\left[\mathrm{~kg} \cdot \mathrm{m}^{2}\right]$} & $m_{p}$ & 66 & {$[\mathrm{~g}]$} \\
$C$ & 0.02 & {$[1 / \mathrm{s}]$} & $C_{0}$ & 0.02 & {$[\mathrm{~N} \cdot \mathrm{m} \cdot \mathrm{s}]$} \\
\hline
\end{tabular}

Table 3 Parameters of the motors

\begin{tabular}{l|c|c}
\hline Type & TS1904 & TS1983 \\
\hline Power $[\mathrm{W}]$ & 60 & 30 \\
\hline Max. torque $[\mathrm{N} \cdot \mathrm{m}]$ & 1.23 & $5.30 \times 10^{-1}$ \\
\hline Inertia $\left[\mathrm{kg} \cdot \mathrm{m}^{2}\right]$ & $2.84 \times 10^{-5}$ & $4.90 \times 10^{-6}$ \\
\hline Damping coeff. $[\mathrm{N} \cdot \mathrm{m} \cdot \mathrm{s}]$ & $2.00 \times 10^{-2}$ & $1.00 \times 10^{-5}$ \\
\hline
\end{tabular}

となる.ただし，

$$
\mathbf{A}=\left[\begin{array}{c|c}
\mathbf{0} & \mathbf{I} \\
\hline-\mathbf{M}^{-1} \mathbf{K} & -\mathbf{M}^{-1} \mathbf{C}
\end{array}\right], \mathbf{B}=\left[\begin{array}{c}
\mathbf{0} \\
\hline \mathbf{M}^{-1} \mathbf{D}
\end{array}\right], \mathbf{x}=\left[\begin{array}{l}
\mathbf{z} \\
\hline \dot{\mathbf{z}}
\end{array}\right]
$$

である.また，本研究では低周波数帯域の挙動に注目 することとし, $n=1$ として 1 次振動モードのみを考 慮する。

\section{3. 実 験 装 置}

マスターアームおよびスレーブアームの実験装置の 外観をそれぞれ図 3，4 に示す．装置の構成を図 5 に 示す. マスターアームはアクリル製の直方体であり, アルミ製の基礎に設置された DC サーボモータ (多摩 川精機，TS1983)の軸に，これを取り付けることによ り製作した．また，スレーブアームは先端に質量を取 り付けたステンレス製の片持はりであり，スチール製 の基礎に設置された DC サーボモータ(多摩川精機, TS1904)のモータ軸と繋がれた回転軸に，フレキシブ ルアームとして取り付けた。製作したマスターアーム とスレーブアームの諸元をそれぞれ表 1 および表 2 に 示し, 使用したモータの仕様を表 3 に示す. スレーブ アームの 1 次, 2 次抢よび 3 次の固有振動数は, それ ぞれ, $2.39 \mathrm{~Hz}, 28.1 \mathrm{~Hz}, 80.7 \mathrm{~Hz}$ であった. 制御系は $\mathrm{PC}$ 上に搭載した DSP(エムティティ, DSP6031) およ び, I/O ボード(エムティティ, DSP6000-EB) 上に搭載 したカウンターモジュール(エムティティ, UDCM-3) を用いて実装した，スレーブアームの柔軟リンクのひ ずみは共和電業製ひずみゲージをハブ側固定端から $l_{s t}$ の位置に貼り付け, 実験用の動ひずみアンプ (共和電 
業, SGI-100A)を用いて計測し, ローパスフィルター を用いて高周波成分を取り除いた後に電圧信号として DSPに取り込んだ。

\section{4. 制 御 系}

この研究では, FMSS に対して受動性に基づく対称 型バイラテラル制御法とともに最適 1 型デジタルサー ボ系を適用する．製作した実験機に対して，受動性に 基づく制御法, 最適 1 型サーボ系を用いた制御法を適 用した.ここでは, マスターアームを初期角度 $0^{\circ}$ か ら手動で $40^{\circ} \sim 50^{\circ}$ 程度動かし, 各制御法を用いてス レーブアームを追従させた。 なお, 状態フィードバッ クを行うために直接観測できない状態変数については オブザーバを用いて推定する.

\section{(a) 受動性に基づく対称型バイラテラル制御}

マスターアームの回転角 $\theta_{m}$ とスレーブアームの回 転角 $\theta$ が一致し, 系が完全に静止した状態を目標の状 態とする.この状態でのマスターアームの回転角 $\theta_{m}$ の目標值を $\Theta_{d}$ とするとき, マスターアームの回転角, スレーブアームの回転角および曲げ変位の定常值をそ れぞれ $\theta_{m d}, \theta_{d}$ および $v_{d}(x)$ とすると,

$$
\theta_{m d}=\theta_{d}=\Theta_{d}, \quad v_{d}(x)=0
$$

となる. ここで, リアプノフ関数

$$
V(\mathbf{s}(t))=\kappa_{1} T_{m}+\kappa_{2}(T+U)+\frac{1}{2} \kappa_{3}\left(\theta_{m}-\theta\right)^{2}
$$

を考える、ただし，

$$
\mathbf{s}(t)=\left[\begin{array}{llllll}
\theta_{m}(t) & \dot{\theta}_{m}(t) & \theta(t) & \dot{\theta}(t) & v(x, t) & \dot{v}(x, t)
\end{array}\right]^{T}
$$

であり, 右辺第 1 項はマスターアームの全エネルギー に対して $\kappa_{1}$ の重み付けをした項, 右辺第 2 項はスレー ブアームの全エネルギーに対して $\kappa_{2}$ の重み付けをし た項, 最終項は $\theta_{m}(t) \rightarrow \theta(t)$ となるような制御側を導 くために付け加えた仮想ポテンシャル項である.ここ で, 目標状態を $\mathbf{s}_{d}(t)=\left[\begin{array}{llllll}\Theta_{d}(t) & 0 & \Theta_{d}(t) & 0 & 0 & 0\end{array}\right]^{T}$ と おくと,

$$
\begin{cases}V(\mathbf{s}(t))=0 & \left(\mathbf{s}(t)=\mathbf{s}_{d}(t)\right) \\ V(\mathbf{s}(t))>0 & \left(\mathbf{s}(t) \neq \mathbf{s}_{d}(t)\right)\end{cases}
$$

を満たすことが分かる．いま，式(17)を式(1)および 式 (10) から (12) の解軌道に沿って時間微分すると,

$$
\begin{aligned}
\frac{d V(\mathbf{s}(t))}{d t}= & \dot{\theta}_{m}\left\{\kappa_{1}\left(\tau_{h}+\tau_{m}\right)+\kappa_{3}\left(\theta_{m}-\theta\right)\right\} \\
& +\dot{\theta}\left\{\kappa_{2} \tau+\kappa_{3}\left(\theta-\theta_{m}\right)\right\} \\
& -C E I \int_{0}^{l} \dot{v}^{\prime \prime \prime \prime}(x, t) \dot{v}(x, t) d x
\end{aligned}
$$

となる. 柔軟アームのひずみをフィードバックする受 動性に基づく制御法 ${ }^{(10)}$ も提案されているが，ひずみの フィードバックによる操作性能の劣化が考えられる ${ }^{(4)}$ ため, ここでは, 標準的な受動性に基づく制御法を適 用して, 入力トルク $\tau_{m}, \tau$ を,

$$
\begin{aligned}
& \tau_{m}=\frac{\kappa_{3}}{\kappa_{1}}\left(\theta-\theta_{m}\right), \\
& \tau=\frac{\kappa_{3}}{\kappa_{2}}\left(\theta_{m}-\theta\right)
\end{aligned}
$$

とする. したがって,

$$
\frac{d V(\mathbf{s}(t))}{d t}=\kappa_{1} \tau_{h} \dot{\theta}_{m}-C E I \int_{0}^{l} \dot{v}^{\prime \prime \prime \prime}(x, t) \cdot \dot{v}(x, t) d x
$$

が導かれる. 式 (21) 中の $\dot{v}^{\prime \prime \prime \prime}(x, t)$ は, 式(13) と (14) から,

$$
\dot{v}^{\prime \prime \prime \prime}(x, t)=\mathbf{W}^{\prime \prime \prime \prime}(x) \dot{\mathbf{q}}(t)=\mathbf{W}(x) \mathbf{N} \dot{\mathbf{q}}(t)
$$

ただし, $\mathbf{N}=\operatorname{diag}\left[k_{1}^{4} \cdots k_{n}^{4}\right]$ と表すことができるので, 式 (21) の最終項は次式に示すように正となる.

$$
\begin{aligned}
& C E I \int_{0}^{l} \dot{v}^{\prime \prime \prime \prime}(x, t) \cdot \dot{v}(x, t) d x \\
& =C E I \int_{0}^{l} \dot{\mathbf{q}}^{T}(t) \mathbf{N}^{T} \mathbf{W}^{T} \mathbf{W} \dot{\mathbf{q}}(t) d x(\equiv \Psi) \geq 0
\end{aligned}
$$

したがって, 式(21)より, 入力 $\tau_{h}$ から出力 $\kappa_{1} \dot{\theta}_{m}$ まで の受動性が

$$
\begin{aligned}
\int_{0}^{t} \tau_{h} \kappa_{1} \dot{\theta}_{m} d t & =\int_{0}^{t} \frac{d V(\mathbf{s}(t))}{d t} d t+\int_{0}^{t} \Psi d t \\
& =V(\mathbf{s}(t))-V(\mathbf{s}(0))+\int_{0}^{t} \Psi d t \\
& \geq-V(\mathbf{s}(0)) \geq \text { (const.) }
\end{aligned}
$$

と示される.

この制御法では, 式 (19) と (20) 中の係数 $\kappa_{1}, \kappa_{2}$ お よび $\kappa_{3}$ を変更することで容易に操作性や追従性を調 整することが可能である.

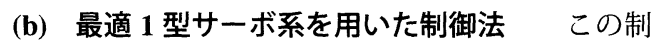
御法では, マスターアームへフィードバックされるト ルクの計算に式(19)を用い, スレーブアームの制御入 力は最適 1 型サーボ系を適用して決定する. スレーブ アームの状態方程式 (16) を離散時間系に変換したシ ステム

$$
\begin{aligned}
& \mathbf{x}(k+1)=\mathbf{A}_{d} \mathbf{x}(k)+\mathbf{B}_{d} u(k)
\end{aligned}
$$

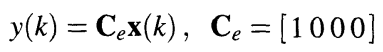

に対し, 次のような拡大エラーシステムを導入する.

$$
\begin{aligned}
& {\left[\begin{array}{c}
e(k+1) \\
\Delta \mathbf{x}(k+1)
\end{array}\right]=\left[\begin{array}{cc}
1 & -\mathbf{C}_{e} \mathbf{A}_{d} \\
\mathbf{0} & \mathbf{A}_{d}
\end{array}\right]\left[\begin{array}{c}
e(k) \\
\Delta \mathbf{x}(k)
\end{array}\right]} \\
& +\left[\begin{array}{c}
-\mathbf{C}_{e} \mathbf{B}_{d} \\
\mathbf{B}_{d}
\end{array}\right] \Delta u(k)+\left[\begin{array}{l}
1 \\
\mathbf{0}
\end{array}\right] \Delta \theta_{d}(k+1)
\end{aligned}
$$

ただし，自標角度 $\theta_{d}$ に対する誤差信号を

$$
e(k)=\theta_{d}(k)-\theta(k)=\theta_{d}(k)-\mathbf{C}_{e} \mathbf{x}(k)
$$

とし， $\Delta$ は一階差分オペレータである.ここで新たな 状態変数べクトル $\mathbf{X}=\left[e(k) \Delta \mathbf{x}^{T}(k)\right]^{T}$ を導入し, 式 (25) を

$$
\mathbf{X}(k+1)=\boldsymbol{\Phi} \mathbf{X}(k)+\mathbf{G} \Delta u(k)+\mathbf{G}_{R} \Delta \theta_{d}(k+1)
$$


と書き改める. 制御の目標値信号 $\theta_{d}$ には $\theta_{m}$ を与え る. 本研究では人間の操作するマスターアームの角度 変化は, サンプリング周期に比べ十分遅いものとし, マスターアームの角度の 1 サンプル周期の変化量 $\Delta \theta_{m}$ は十分小さいと仮定する．このとき， $\theta_{m}$ はほぼ一定 とみなすことができるため, 目標值信号 $\theta_{d}$ がステッ プ信号または一定值であるとすると, 值が変化する時 間以外では $\Delta \theta_{d}=0$ なので，式 (27) は次式のように なる.

$$
\mathbf{X}(k+1)=\boldsymbol{\Phi} \mathbf{X}(k)+\mathbf{G} \Delta u(k)
$$

このシステムに対して次の評価関数を定義する。

$$
J_{s}=\sum_{k=1}^{\infty}\left[\mathbf{X}^{T}(k) \mathbf{Q}_{s} \mathbf{X}(k)+\Delta u^{T}(k) H_{s} \Delta u(k)\right]
$$

ここで $\mathbf{Q}_{s}$ と $H_{s}$ は設計者が決める重みである. 式(28) のエラーシステムに対し, 式 (29) の評価関数を最小 とする最適制御入力 $\Delta u(k)$ は, 最適レギュレータ理論 により定常 Riccati 方程式の解を用いて次のように求 まる。

$$
\Delta u(k)=\mathbf{F}_{s} \mathbf{X}(k)=\left[\begin{array}{ll}
F_{e} & \mathbf{F}_{x}
\end{array}\right]\left[\begin{array}{c}
e(k) \\
\Delta \mathbf{x}(k)
\end{array}\right]
$$

(c) 状態推定精度の改善 次章で実験によって示 すが，(a)と(b)のいずれの制御法についても，スレー ブアームが物体への接触を伴わない場合には, 同一次 元オブザーバーによって十分な状態推定精度が得られ るが, 物体への接触中には十分な状態推定精度が得ら れない．これはオブザーバーに用いた制御モデルには 物体への接触力が考慮されていないことに起因する. そこで, この研究では外乱を考慮したオブザーバー(11) を採用し，状態推定の精度を改善する。ここでは簡単 に概要を述べる.

システムに入力される外乱 $\mathbf{d}(k)$ を考慮して状態方 程式を次のように表す。

$$
\begin{aligned}
& \mathbf{x}(k+1)=\mathbf{A}_{d} \mathbf{x}(k)+\mathbf{B}_{d} \mathbf{u}(k)+\mathbf{E}_{d} \mathbf{d}(k) \\
& \mathbf{y}(k)=\mathbf{C}_{c} \mathbf{x}(k), \mathbf{C}_{c}=\left[\begin{array}{cccc}
1 & 0 & 0 & 0 \\
0 & 0 & 1 & 0 \\
0-\frac{h}{2} \phi_{1}^{\prime \prime}\left(l_{s t}\right) & 0 & 0
\end{array}\right]
\end{aligned}
$$

ただし, 入力される外乱が状態変数に与える影響を考 慮して, この研究では

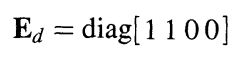

とした.このシステムに対し，次のような 1 型デジタ ルサーボ系をオブザーバとして用いることができる.

$$
\begin{aligned}
& \hat{\mathbf{x}}(k+1)=\mathbf{A}_{d} \hat{\mathbf{x}}(k)+\mathbf{B}_{d} \mathbf{u}(k)+\mathbf{E}_{d} \hat{\mathbf{d}}(k) \\
& \hat{\mathbf{y}}(k)=\mathbf{C}_{c} \hat{\mathbf{x}}(k), \mathbf{e}(k)=\mathbf{y}(k)-\hat{\mathbf{y}}(k) \\
& \hat{\mathbf{d}}(k)=\mathbf{K}_{e} \sum_{i=1}^{k} \mathbf{e}_{i}+\mathbf{K}_{x}(\hat{\mathbf{x}}(k)-\hat{\mathbf{x}}(0))+\hat{\mathbf{d}}(0)
\end{aligned}
$$

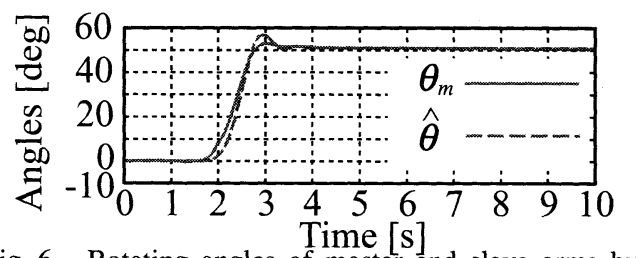

Fig. 6 Rotating angles of master and slave arms by controller (a)

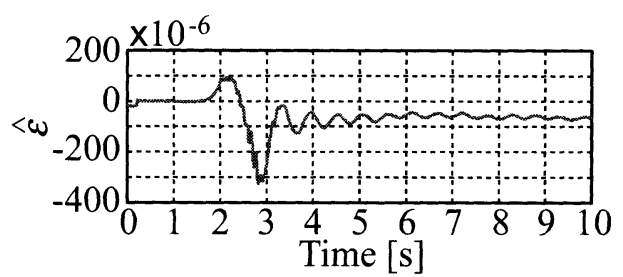

Fig. 7 Estimated strain of slave arm by controller (a)

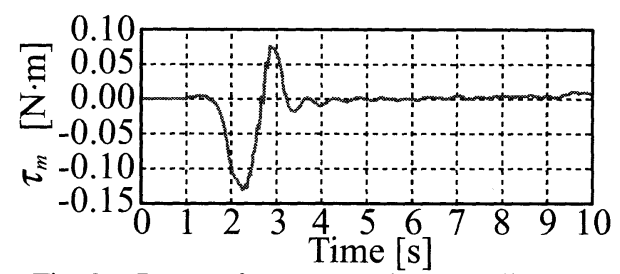

Fig. 8 Torque of master arm by controller (a)

$\mathbf{K}_{e}$ および $\mathbf{K}_{x}$ はそれぞれ推定誤差の積分および推定誤 差に対するオブザーバーへのフィードバックゲインで あり, 最適レギュレータ理論等を用いて決定すること ができるが，本研究では，直接フィードバックゲイン を調整してオブザーバーが安定となるよう試行錯誤を 行い, 以下の值を用いた。

$$
\mathbf{K}_{e}=\left[\begin{array}{ccc}
-0.5 & 0 & 0 \\
0 & 0 & 13.31 \\
& \mathbf{0}_{2 \times 3}
\end{array}\right], \mathbf{K}_{x}=\operatorname{diag}\left[\begin{array}{llll}
-1 & -1 & 0 & 0
\end{array}\right]
$$

\section{5. 実 験 結 果}

この章では, マスターアーム角度 $\theta_{m}$ とスレーブアー 厶角度 $\theta$ の定常偏差の収束性を追従性と呼ぶ。また, マスターアームの操作に対するスレーブアームの応答 の速さを即応性, マスターアームの操作時の操作の軽 さを操作性と呼ぶ，そして, 制御法 (a) と (b) の特徴 の比較を行い，提案するオブザーバー (c) によって状 態推定精度が大きく改善することを示す.

はじめに，同一次元オブザーバーを用いて状態推定 を用い，障害物を設置せずに FMSS を動作させた場 合の実験結果を図 6 から 11 に示す. 図 6 から 8 は受 動性に基づく制御法 (a)による結果であり，追従性を 重視して係数を調整した場合の実験結果を示すここの とき式 (19) と (20) 中の各係数は $\kappa_{1}=1.0, \kappa_{2}=1.0$, $\kappa_{3}=1.0$ とした. 角度の応答 (図 6) では, マスターアー 


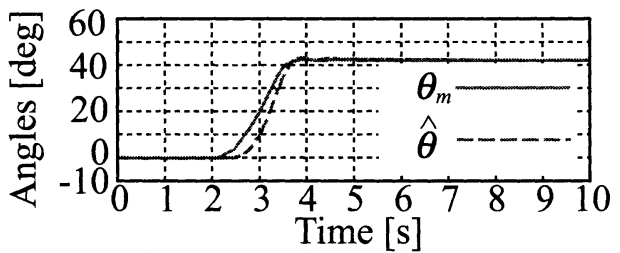

Fig. 9 Rotating angles of master and slave arms by controller (b)

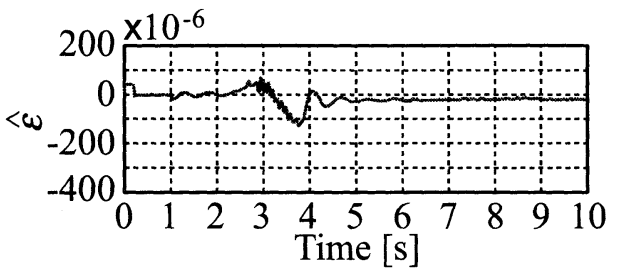

Fig. 10 Estimated strain of slave arm by controller (b)

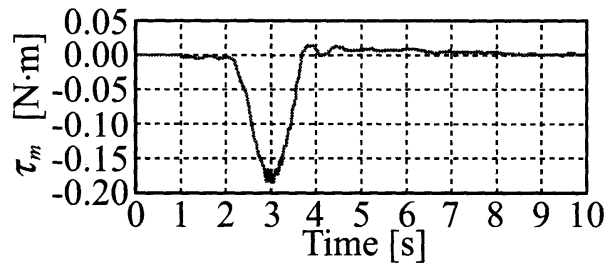

Fig. 11 Torque of master arm by controller (b)

ム角度 $\theta_{m}$ とスレーブアーム角度 $\theta$ の推定結果 $\hat{\theta}$ を示 し、ひずみの応答(図 7)では,ひずみの推定結果 $\hat{\varepsilon}, 反$ 力の応答 (図 8)では, マスターアームにフィードバッ クされる反力 $\tau_{m}$ の応答を示す．追従性を重視して調 整を行うと, 図 7 に見られるようアーム移動後に振動 が生じることが分かる. 係数を調整して追従性を落と すことで振動を抑制することは可能だが，制振をアク ティブには行っていないため, 大きな振動抑制効果は 得られなかった. 図 9 から 11 は最適 1 型サーボ系 (b) による結果である．ここでは，式 (19) 中の各係数は $\kappa_{1}=1.0, \kappa_{3}=1.0$ とし, 式 (29) 中の重みは $\mathbf{Q}_{s}=\mathbf{I}$, $H_{s}=10^{4}$ とした. 図 6 と図 9 を比較すると, 角度に 関しては (a) の制御法に比べ (b) の制御法は即応性で は劣っている. しかしオーバーシュートが見られず追 従性が良いことが分かる. また，図10に示すように, アームの移動後に速やかに振動が抑制されているのが 分かる. 図 11 を見ると (a) の制御法を用いた場合より 反力が大きくなっている．これは即応性が低下した結 果 $\theta$ と $\theta_{m}$ の差が大きくなり, 式 (19) で計算される $\tau_{m}$ が大きくなったためである. この場合マスターアーム の操作感が重く感じられるようになる.

次に, スレーブアームの角度 $\theta$ が可動範囲内である

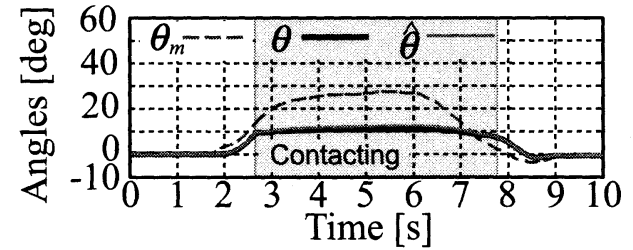

Fig. 12 Rotating angles by controller (a) and full-order observer during contacting with a object

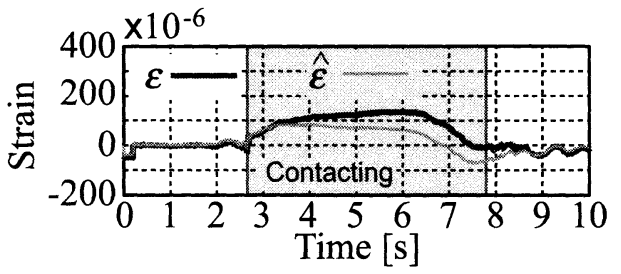

Fig. 13 Estimated strain by controller (a) and full-order observer during contacting with a object

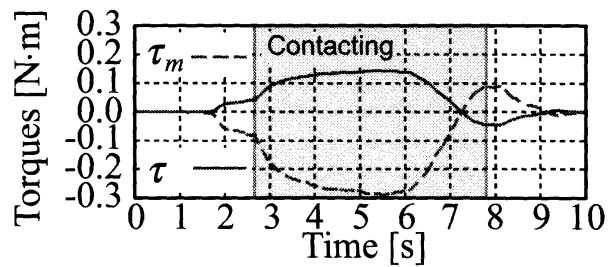

Fig. 14 Input torques by controller (a) and full-order observer during contacting with a object

約 $10^{\circ}$ の位置にスチール製の直方体の物体を障害物と して設置し，マスターアームを操作することによりス レーブアームを物体に接触させ，接触後も一定時間物 体にスレーブアームを押し付けた後マスターアームを 戻してスレーブアームを物体から離す実験を行った。 図 12 から 14 は, 同一次元オブザーバーを用いて状態 推定を行った制御法 (a)による結果である.ここでは, 追従性と操作性を調整し, 式 (19) と (20) 中の各係数 は $\kappa_{1}=1.0, \quad \kappa_{2}=2.0, \quad \kappa_{3}=1.0$ とした. このときス レーブアームが物体に接触した感覚がマスターアーム を通して感じられ，操作性についても良好であった， 図 15 から 17 は, 同一次元オブザーバーを用いて状態 推定を行った制御法 (b) による結果である. このとき 式 (19) 中の各係数は $\kappa_{1}=1.0, \kappa_{3}=1.0$ とし, 式 (29) 中の重みは $\mathbf{Q}_{s}=\mathbf{I}, H_{s}=10^{4}$ とした. 物体にスレー ブアームを押し付けた後, マスターアームを操作して スレーブアームを離そうとした際, スレーブアームが すぐには物体から離れずマスターアームの操作が重く なり操作性が悪化した．図 17 に示すように，制御法 (b)では，例えば制御法 (a) の図 14 で見られるような 物体への接触中に正負が逆転した作用・反作用を表す トルクの関係が満足されなくなることが分かり, 約 7 


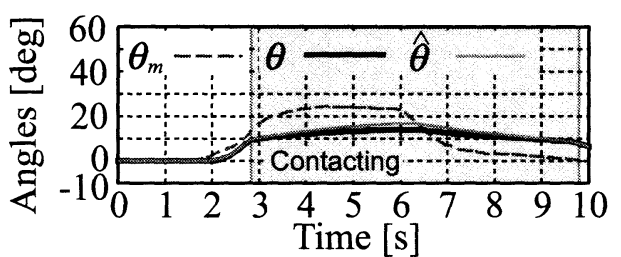

Fig. 15 Rotating angles by controller (b) and full-order observer during contacting with a object

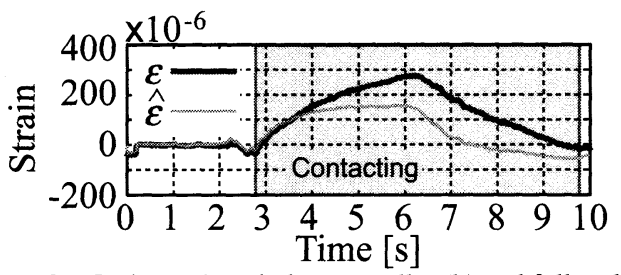

Fig. 16 Estimated strain by controller (b) and full-order observer during contacting with a object

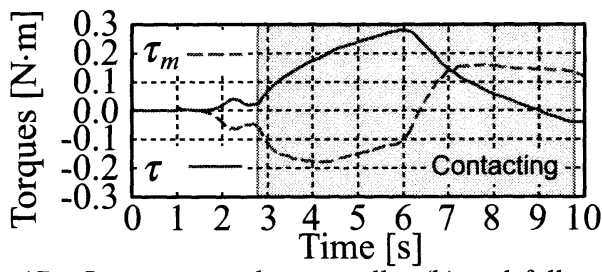

Fig. 17 Input torques by controller (b) and full-order observer during contacting with a object

秒以降はマスターアームの操作方向とは逆向きのトル クがマスターアームにフィードバックされていること が分かる．スレーブアーム先端と物体が接触中には, スレーブアームへの入カトルク $\tau$ と物体から受ける スレーブアーム先端への反力とが釣合った状態で，マ スターアーム角度 $\theta_{m}$ とスレーブアームのハブ角度 $\theta$ の定常偏差を減少するように 1 型サーボ系の誤差の積 分項が増大して入力 $\tau$ が増大する. スレーブアーム先 端を物体から離すようにマスターアームを操作しても 積分項はすぐには減少せず，物体に押付け力を作用さ せた状態を維持し，マスターアームとスレーブアーム のハブの角度の差 $\left(\theta-\theta_{m}\right)$ の符号が反転して初めて 積分項が減少し, 押し付け力が減少していくこととな る.このとき, 式(19) で計算されるマスターアームへ のフィードバックトルク $\tau_{m}$ がマスターアームの操作 を妨げる方向に作用することとなり操作性が悪化した と考えられる. ただし，マスターアームの操作速度が 十分小さい場合にはこのような現象の影響は小さくな る. また, 図 13 と 16 の結果から, (a) と (b) のいずれ の制御法についても，同一次元オブザーバーを用いた 場合には, 物体への接触中に十分な状態推定精度を確 保できないことが分かる.これはオブザーバーに用い

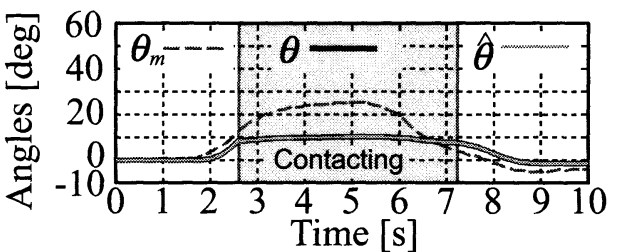

Fig. 18 Rotating angles by controller (a) and observer (c) during contacting with a object

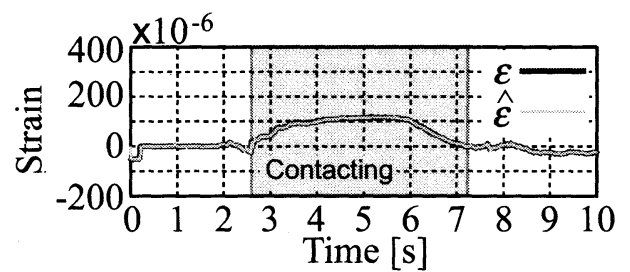

Fig. 19 Estimated strain by controller (a) and observer (c) during contacting with a object

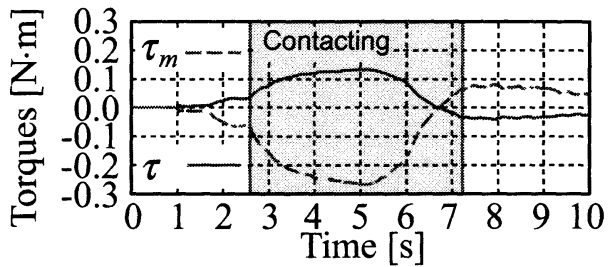

Fig. 20 Input torques by controller (a) and observer (c) during contacting with a object

た制御モデルには物体への接触力が考慮されていない ことに起因する.

それぞれの制御法について，(c)で述べた方法を用 いて状態推定を行った場合の結果を図 18 から 23 に 示す. 図 18 から 20 は, 式 (19) と (20) 中の各係数を $\kappa_{1}=1.0, \kappa_{2}=2.0, \kappa_{3}=1.0$ とした場合の制御法 (a) に よる結果であり, 図 21 から 23 は, 式(19) 中の各係数 を $\kappa_{1}=1.0, \kappa_{3}=1.0$ とし, 式 (29) 中の重みを $\mathbf{Q}_{s}=\mathbf{I}$, $H_{s}=10^{4}$ とした場合の制御法 (b) による結果である. 提案するオブザーバーによる状態推定精度については, いずれの制御法についても，実測値と推定值はよく一 致しており, 物体への接触中に正確な状態推定值が得 られていることが分かる. 提案するオブザーバーの推 定值を用いた制御法 (a) および制御法 (b) の制御性能 については，同一次元オブザーバーを用いた場合と大 きな差は見られない，制御法 (a) ではスレーブアーム が物体に接触した感覚がマスターアームを通して感じ られ，操作性についても良好であり，制御法 (b)では 図 23 に示すように, 図 17 と同様に, マスターアーム の操作性が悪化していることが分かる.

制御法 (a) および (b) の利点と欠点は以下のとおりで ある. 制御法 (a) ではスレーブアームの振動の収束が 


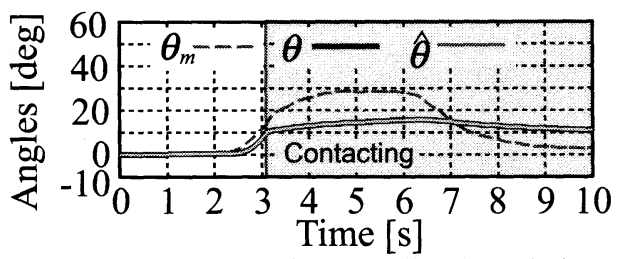

Fig. 21 Rotating angles by controller (b) and observer (c) during contacting with a object

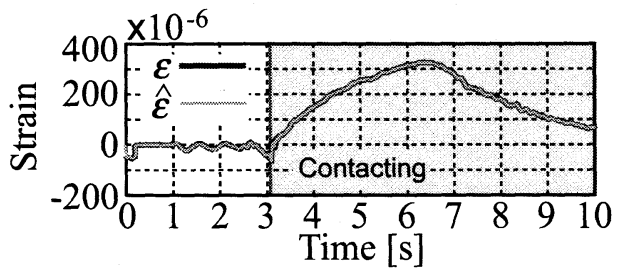

Fig. 22 Estimated strain by controller (b) and observer

(c) during contacting with a object

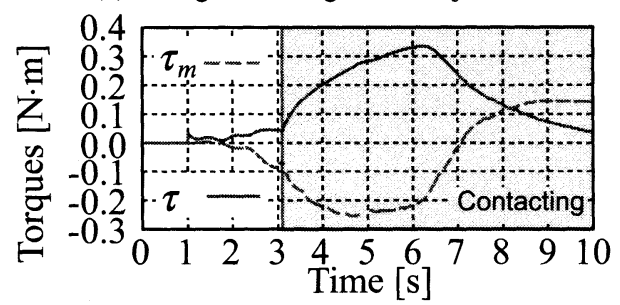

Fig. 23 Input torques by controller (b) and observer (c) during contacting with a object

遅いが, 物体への接触直後もマスターアームの操作が 重くならず操作性が良好である. 一方, 制御法 (b) で はスレーブアームの振動の収束が早く, スレーブアー ムがマスターアームに定常偏差なく追従するが, 動作 速度が大きい場合にマスターアームの操作が重くなる 特徵があり, 物体への接触時にこの傾向が顕著となる. したがって, マスターアームの動作速度が大きい場合 には制御法(a), マスターアームの動作後のアーム動作 速度が小さい場合には振動抑制の観点から制御法 (b) が適していると考えられる.いずれの制御法について も, 提案するオブザーバーによって物体への接触時の 状態推定值精度が大きく改善する.

\section{6. 結 論}

本研究ではマスターースレーブシステムのスレー ブアームの軽量化に伴う問題を研究するため, スレー ブアームに柔軟アームを用い, 物体への接触を伴う FMSS の運動と力の制御について研究を行った.

オブザーバーを用いた状態推定を行い, フィードバッ ク制御系を構築した. 同一次元オブザーバーを用いた 場合, スレーブアームが物体への接触を伴わない場合 には十分な推定精度が得られたが, 物体への接触中に
は推定精度が低下した，そこで，本研究では接触力に よる外乱を考慮してオブザーバーの設計を行うことで, 物体への接触を伴う FMSS の状態推定精度を向上でき ることを示した.

受動性に基づくバイラテラル制御法と最適 1 型サー ボ系による制御法にはそれぞれ利点と欠点がある. 現 在はこれらの制御法をファジィ制御によって併用する ことによって制御性能を向上する手法の研究を進めて おり，良好な結果が得られている．これについては別 報での報告を予定している.

\section{文献}

(1) Sirouspour, S. and Shahdi, A., Model Predictive Control for Transparent Teleoperation Under Communication Time Delay, IEEE Transactions on Robotics, Vol.22, No.6(2006-12), pp.1131-1145.

(2) Lee, D. and Spong, M. W., Passive Bilateral Teleoperation with Constant Time Delay, IEEE Transactions on Robotics, Vol.22, No.2(2006-4), pp.269-281.

(3) Hannaford, B. and Ryu, J. -H., Time Domain Passivity Control of Haptic Interfaces, IEEE Transactions on Robotics and Automation, Vol.18, No.1(2002-2), pp.1-10.

(4) Mori, T., Morita, Y., Ukai, H. and Kando, H., Operation Assist and Evaluation for Flexible MasterSlave Manipulators, Transactions of the Japan Sciety of Mechanical Engineers, Series C, Vol.72, No.719(2006-7), pp.2162-2168.

(5) Abe K., Yamakawa S., and Fujimoto H., Measurement of the Differential Limen of the Time Derivative of Force for Master-Slave System Design, Proceedings of Robotics and Mechatronics Conference 2004 (2004), 2A1-H1 (CDROM).

(6) Kanamori, N., Tanaka, T. and Tanaka, K., Subjective Evaluation of Operating Feeling in a Haptic Interface, Transactions of the Japan Sciety of Mechanical Engineers, Series C, Vol.68, No.669(2002-5), pp.1467-1473.

(7) Shao H. and Nonami K., Bilateral Control of Tele-Hand System with Neuro-Fuzzy Scheme, The Industrial Robot, Vol.33, No.3 (2006), pp.216-227.

(8) Kitamura T., Tsujiuchi N. and Koizumi T., Motion Discrimination and Joint Angle Estimation of an Arm using EMG Signals, Proceedings of the Dynamics and Design Conference 2005 (2005-8), 410 (CD-ROM).

(9) Ashida S., Sugie T., and Osuka K., Master Slave Control of Two Armed Rescue Manipulator, Proceedings of Robotics and Mechatronics Conference 2004 (2004), 2A1-H41 (CD-ROM).

(10) Mori, T., Morita, Y., Ukai, H. and Kando, H., Bilateral Control Based on Passivity for Flexible Masterslave Manipulators, Proceedings of the JSME Robotics Mechatoronics Conference 2004, No.04-4 (2004-6), 2A1L1-39.

(11) Hoshino, Y., Kobayashi, Y. and Yamada, G., Vibration Control Using a State Observer that Considers Disturbances of a Golf Swing Robot, JSME International Journal, Series C, Vol.48, No.1 (2005), pp.60-69. 